\title{
LATERAL MOVEMENT AND STABILITY OF CHANNEL BANKS NEAR TWO HIGHWAY CROSSINGS IN THE PASCAGOULA RIVER BASIN IN MISSISSIPPI
}

By D. Phil Turnipseed

U.S. GEOLOGICAL SURVEY

Water-Resources Investigations Report 93-4131

Prepared in cooperation with the MISSISSIPPI DEPARTMENT OF TRANSPORTATION

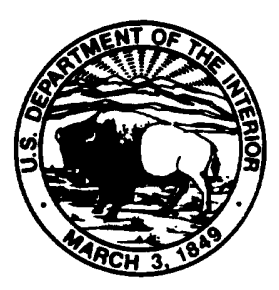

Jackson, Mississippi 1993 


\section{U.S. DEPARTMENT OF THE INTERIOR}

BRUCE BABBITT, Secretary

U.S. GEOLOGICAL SURVEY

Robert M. Hirsch, Acting Director

For additional information write to:

\section{District Chief}

U.S. Geological Survey

Suite 710, Federal Building

100 W. Capitol Street

Jackson, Mississippi 39269
Copies of this report can be purchased from:

U.S. Geological Survey

Earth Science Information Center

Open-File Reports Section

Box 25286, MS 517, Federal Center

Denver, CO 80225 


\section{CONTENTS}

Page

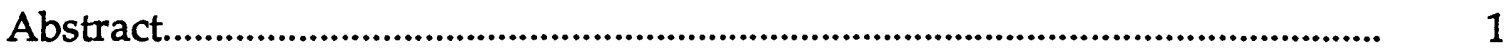

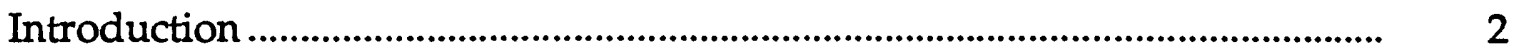

Purpose and scope ......................................................................................... 3

Description of the study areas ................................................................... 5

Chickasawhay River at State Highway 63 at Leakesville......... $\quad 5$

Leaf River at U.S. Highway 98 near McLain................................ 5

Acknowledgments............................................................................................... 6

Determination of lateral bank movement ...........................................................

Aerial photography mapping .................................................................... $\quad 7$

Mapping error .............................................................................................. 7

Sinuosity computation ..................................................................................... 8

Geographic information system ...............................................................

Channel stability ....................................................................................................... 10

Soil properties .............................................................................................. 10

Channel-bank geometry ............................................................................ 10

Analysis of channel characteristics.......................................................................... 10

Bank movement ............................................................................................. 13

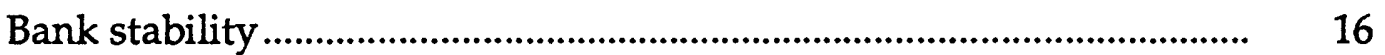

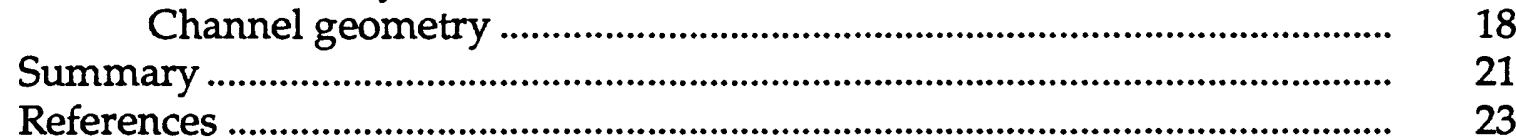




\section{ILLUSTRATIONS}

Page

Figure 1. Map showing location of study sites in the Pascagoula River Basin in Mississippi

2. Example of tops of channel banks and apparent channel shift caused by errors introduced during mapping and digitizing for the Pearl River in the vicinity of U.S. Highway 84 near Monticello, Mississippi

3. Cross sections from soundings made during historical and recent discharge measurements at the existing State Highway 63 crossing of the Chickasawhay River at Leakesville, Mississippi

4. Cross sections from soundings made during historical and recent discharge measurements at the existing U.S. Highway 98 crossing of the Leaf River near McLain, Mississippi

5. Map showing tops of channel banks from 1942 to 1985 in the vicinity of the existing and proposed State Highway 63 crossing of the Chickasawhay River at Leakesville, Mississippi

6. Map showing tops of channel banks from 1942 to 1985 in the vicinity of the existing and proposed U.S. Highway 98 crossing of the Leaf River near McLain, Mississippi

7. Graph showing change in sinuosity with time near the U.S. Highway 98 crossing of the Leaf River near McLain and the State Highway 63 crossing of the Chickasawhay River at Leakesville, Mississippi

8. Cross section showing probable critical failure surfaces for channel banks at the existing State Highway 63 crossing of the Chickasawhay River at Leakesville, Mississippi.

9. Cross section showing probable critical failure surfaces for channel banks at the existing U.S. Highway 98 crossing of the Leaf River near McLain, Mississippi 


\section{CONVERSION FACTORS AND VERTICAL DATUM}

Multiply

inch (in.)

foot (ft)

mile (mi)

square mile $\left(\mathrm{mi}^{2}\right)$

foot per mile $(\mathrm{ft} / \mathrm{mi})$

cubic foot per second $\left(\mathrm{ft}^{3} / \mathrm{s}\right)$
By

25.40

0.3048

1.609

2.590

0.1894

0.0283 $\underline{\text { To obtain }}$

millimeter (mm)

meter

kilometer

square kilometer meter per kilometer cubic meter per second

Mississippi Department of Transportation Datum: In this report, elevations are referenced to Mississippi Department of Transportation Datum (MDOTD)--a sitespecific datum. At these sites elevations referenced to MDOTD are to the National Geodetic Vertical Datum of 1929 (NGVD of 1929)--a datum derived from a general adjustment of the first-order level nets of both the United States and Canada, formerly called Sea Level Datum of 1929 and referred to in this report as sea level. 


\title{
LATERAL MOVEMENT AND STABILITY OF CHANNEL BANKS NEAR TWO
} HIGHWAY CROSSINGS IN THE PASCAGOULA RIVER BASIN

IN MISSISSIPPI

By D. Phil Turnipseed

\begin{abstract}
The meandering of alluvial streams has caused localized channel-bank instability that has endangered bridge structures in Mississippi. Knowledge of the movement of channel banks in the vicinity of bridge crossings is important in bridge design. The lateral movement of channel banks at the existing and proposed crossings of both State Highway 63 at the Chickasawhay River at Leakesville and U.S. Highway 98 at the Leaf River near McLain in the Pascagoula River Basin was studied by mapping meanders at various times and measuring channel geometry and soil strength at these sites.

Historical aerial photography was used to determine cartesian coordinates of tops of channel banks, channel-bank widths and lengths, and land use in the stream drainage basins, as well as to map the lateral movement of channel banks at the two study sites. Photographic data were quantified and entered into a geographic information system. Historical channel meandering at the sites was studied to determine patterns of change. Also, change in sinuosity (river length/ valley length) was computed through time.

General and site-specific soils data and channel geometry were collected at both study sites. Site-specific soils data, such as shear-strength properties of bank materials, in combination with hydraulic data, were used to compute existing channel-bank stability and to determine critical failure surfaces near the existing and proposed crossings of the Chickasawhay and Leaf Rivers.

Although no recent significant lateral movement of channel banks was detected at the existing crossings, movement was detected upstream from both proposed alignments. Channel cross sections obtained at the existing State Highway 63 crossing of the Chickasawhay River between 1942 and 1990 indicated about 7 feet of scouring of the thalweg at the bridge. As much as 8 feet of scour of the channel bed was indicated by temporal changes in channel cross sections at the existing U.S. Highway 98 crossing of the Leaf River. Change in sinuosity was not significant for either study site.
\end{abstract}




\section{INTRODUCTION}

Rivers are subject to continuous morphological change. In alluvial river systems, it is the rule rather than the exception that banks will erode, sediments will be deposited, and flood plains and side channels will undergo modification with time (U.S. Department of Transportation, 1975). Changes in the meanders of rivers occur naturally, but can be accelerated when a channel is modified by engineering practices such as dredging, clearing, snagging, or straightening. Lateral erosion problems caused by river meander changes can result in loss of arable land and endangerment of human life. Floods and droughts have been shown to accelerate these channel meandering and adjustment processes (Shen, 1971).

Many scientists have studied channel meandering and related changes in channel geometry. Linsley and others (1982) determined the median length of meandering streams to be about 1.5 times the valley length. Nanson and Hickin (1986) concluded the rate of channel migration (M) for streams in western Canada likely has the following relation:

$$
M=f(w, W, D 50, h, r),
$$

where:

\begin{tabular}{|c|c|}
\hline M & is rate of channel migration; \\
\hline w & is stream power (product of discharge \\
\hline W & $\begin{array}{l}\text { and slope per unit area of the bed) } \\
\text { is channel width: }\end{array}$ \\
\hline D50 & $\begin{array}{l}\text { is median size of the sediment in the } \\
\text { base of the channel: }\end{array}$ \\
\hline $\mathbf{n}$ & is bank height; and \\
\hline & is bend radius of curvatur \\
\hline
\end{tabular}

Nanson and Hickin attributed about 70 percent of channel-bank movement of streams monitored in western Canada to these few hydraulic and sedimentological variables. Osman and Thorne (1988) studied the relations between vertical and lateral erosion of channels and bank material properties, bank geometry, type of bed material, and flow characteristics.

Meandering alluvial streams can cause localized channel-bank instability that can contribute to bridge failure. For example, in 1989, the State Highway 35 crossing of the Pearl River near Carthage, Miss., was endangered by the near failure of a pile bent. Although the near collapse of the bridge was caused by local scour around the pile bent, the problem began when the channel changed course near the crossing. 
In another area of Mississippi, channel widening on the Homochitto River at State Highway 33 at Rosetta resulted in channel widths 2 to 3 times the channel-bank widths that existed in about 1906 and necessitated replacement of the bridge in 1975. By 1974, the top of the right (north) channel bank at a railroad crossing upstream of State Highway 33 had moved about $600 \mathrm{ft}$ north of the main truss to an approach bridge span (Wilson, 1979).

Concern about the lateral movement of river banks and about the effects of bank erosion on bridges has emphasized the need for the development of techniques to define and estimate channel meandering. One possible approach is to study the historical patterns of channel migration by using remote sensing techniques and a geographic information system (GIS). The channel migration patterns, when used in combination with shear-strength properties of the soil and hydraulic flow information, can be used to monitor rates and direction of lateral erosion.

The U.S. Geological Survey (USGS), in cooperation with the Mississippi Department of Transportation (MDOT), began an investigation in 1990 to develop methods for estimating channel meandering at selected bridge sites in Mississippi. The MDOT proposes to realign and reconstruct the State Highway 63 crossing of the Chickasawhay River at Leakesville and the U.S. Highway 98 crossing of the Leaf River near McLain, Miss. (fig. 1). Because lateral movement and bank erosion have occurred recently on the Chickasawhay and Leaf Rivers near these sites, the USGS also studied bank stability at these sites.

The overall purpose of the study was to develop methodology to assess past channel movement and current bank stability and correlate this information with soil properties of channel banks, hydraulic and hydrologic data and recorded floods that probably initiated and provided the driving force behind much of the historical bank movement at these sites. The methodology may be used in other studies to estimate bank erosion, but data were insufficient in this study to predict channel meandering at the study sites.

\section{Purpose and Scope}

This report describes lateral movement and stability of channel banks near the State Highway 63 crossing of the Chickasawhay River at Leakesville and near the U.S. Highway 98 crossing of the Leaf River near McLain. Specific objectives of the study at these sites were to:

(1) map and define past rates and direction of meandering;

(2) measure planform change in channel dimensions and patterns;

(3) digitally simulate the defined past channel meandering; and

(4) relate patterns of change to available hydraulic and hydrologic data and shear-strength properties of the channel-bank material. 


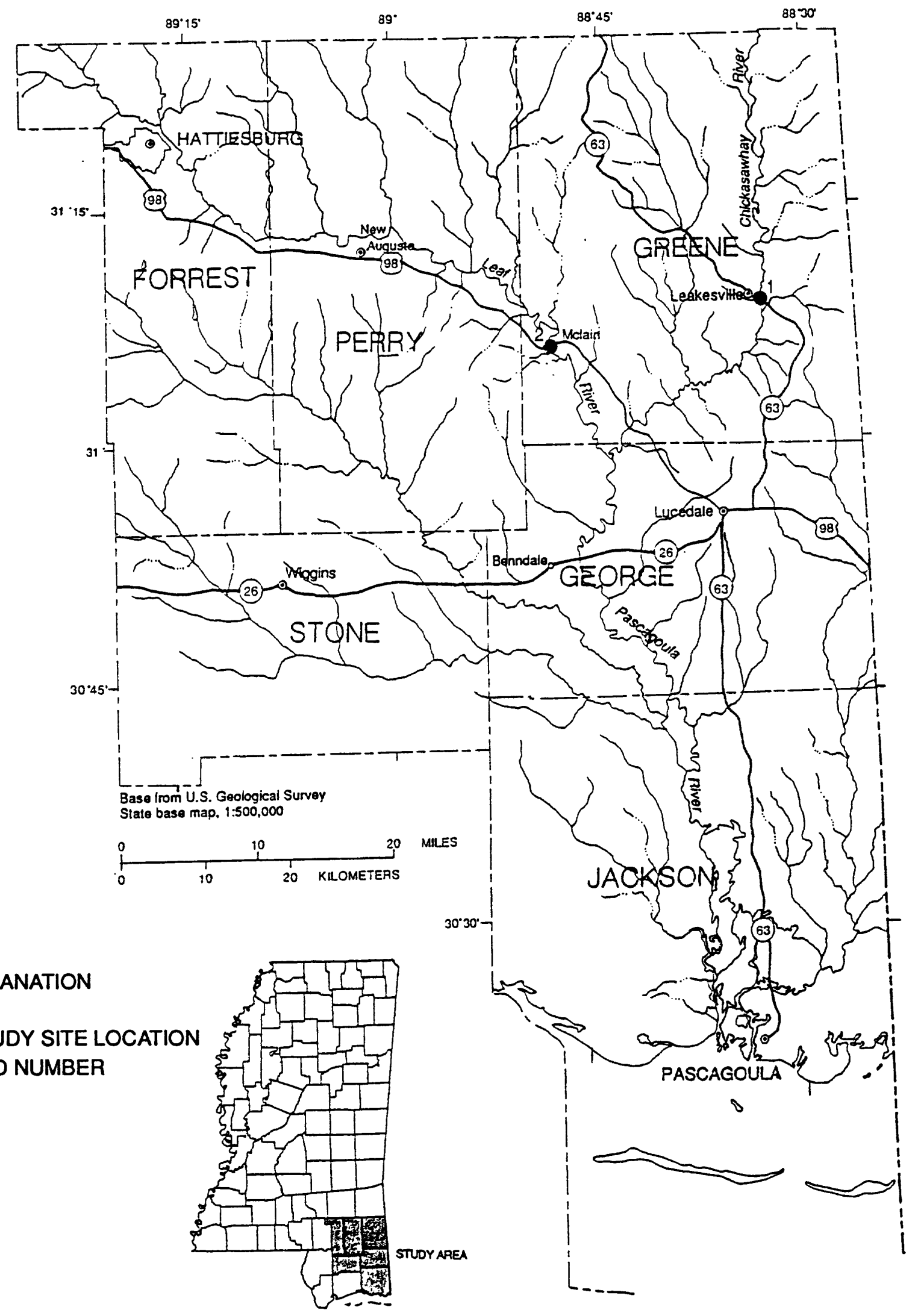

MISSISSIPPI

Figure 1.-- Location of study sites in the Pascagoula River Basin in Mississippi. 


\section{Description of the Study Areas}

Two sites were selected by the USGS and the MDOT in the Pascagoula River Basin in southeastern Mississippi as reaches of river that have had active lateral movement of channel banks in the last 50 years. The MDOT proposes to reconstruct and realign both crossings. The two study sites are near the following existing and proposed highway crossings (fig. 1):

(1)Chickasawhay River at State Highway 63 at Leakesville;

(2)Leaf River at U.S. Highway 98 near McLain.

For each site, about a $10-\mathrm{mi}$ reach of river, centered at these crossings, was monitored in an effort to define the meander processes occurring.

\section{Chickasawhay River at State Highway 63 at Leakesville}

The Chickasawhay River at the State Highway 63 site has a drainage area of $2,690 \mathrm{mi}^{2}$. The length of the channel from the site to the basin divide is about $184 \mathrm{mi}$, and the average slope of the channel between points 10 and 85 percent of the length upstream of the site is about $1.6 \mathrm{ft} / \mathrm{mi}$. The crossing has been the site of a continuous discharge gaging station since 1939. The 50- and 100-year floods are about 80,500 and $96,800 \mathrm{ft}^{3} / \mathrm{s}$, respectively (Landers and Wilson, 1991). The largest recorded flood at this site peaked on February 28, 1961. The peak discharge was about $73,500 \mathrm{ft}^{3} / \mathrm{s}$ at an elevation of $84.6 \mathrm{ft}$ (Wilson and Landers, 1991). The MDOT proposes to realign the State Highway 63 crossing of the Chickasawhay River at Leakesville about $640 \mathrm{ft}$ upstream of the existing crossing.

The flood plain is heavily wooded and channel meandering has occurred both upstream and downstream of the State Highway 63 crossing of the Chickasawhay River. Oxbow lakes are common throughout the valley. Channel banks in the relatively straight reach of the river upstream and downstream of the bridge have remained fairly stable, but channel banks at bends in the river upstream and downstream of the crossing have been subject to bank erosion and channel migration. Development of cutbanks upstream of the existing and proposed bridges could cause unstable channel banks. Natural meander cutoffs have occurred upstream and downstream of the State Highway 63 crossing in the past 50 years (since about 1940). A cutoff occurred between 1942 and 1952, about 0.9 mi upstream of the State Highway 63 crossing, and formed an oxbow lake on the left (east) flood plain.

\section{Leaf River at U.S. Highway 98 near McLain}

The Leaf River at the U.S. Highway 98 site has a drainage area of $3,500 \mathrm{mi}^{2}$. The length of the channel from the site to the basin divide is about $169 \mathrm{mi}$, and the average slope of the channel between points 10 and 85 percent of the length upstream of the site is about $1.9 \mathrm{ft} / \mathrm{mi}$. The crossing has been the site of a 
continuous stage gaging station since before 1928 and a continuous discharge gaging station since 1939. The 50- and 100-year floods are about 115,000 and $135,000 \mathrm{ft}^{3} / \mathrm{s}$, respectively (Landers and Wilson, 1991). Large floods occurred in 1900, 1961, and 1974 at this site. Flood peak discharges and approximate recurrence intervals are listed below (Wilson and Landers, 1991):

\begin{tabular}{cccc}
\hline Year & $\begin{array}{c}\text { Elevation above } \\
\text { sea level } \\
\text { (feet) }\end{array}$ & $\begin{array}{c}\text { Discharge } \\
\text { (cubic feet per second) }\end{array}$ & $\begin{array}{c}\text { Recurrence interval, } \\
\text { approximate } \\
\text { (years) }\end{array}$ \\
\hline & & & \\
1900 & 74.0 & 131,000 & 100 \\
1961 & 73.8 & 128,000 & 100 \\
1974 & 72.5 & 110,000 & 50 \\
\hline
\end{tabular}

The MDOT proposes to realign and add an additional two lanes to provide a four-lane highway at the U.S. Highway 98 crossing of the Leaf River near McLain. The new alignment is about $1,800 \mathrm{ft}$ upstream of the existing alignment.

The banks and flood plain near the crossing are heavily wooded, and lateral movement of the banks has been slow in the past 50 years. Although severe cutting meanders are characteristic of the streams, none were located near the existing or proposed bridges. The main channel shifted toward the right (west) bank from 1941 to 1951; consequently, the thalweg (lowest point of flow) of the channel was no longer between the main channel piers. In 1952, two steel $\mathrm{H}$-pile spurs were constructed at the right (west) bank upstream of the bridge and rock riprap was placed in the channel bed underneath the bridge and around the H-pile spurs. These countermeasures successfully relocated the thalweg of the channel between the main channel piers (Brice and others, 1978). The development of cutbanks upstream of the existing and proposed bridges could cause further unstable channel banks at the site.

\section{Acknowledgments}

The author is indebted to members of the Mississippi Department of Transportation, Hydraulics Division, who provided bridge plans, inspection records, departmental reports and other documentation during the course of this study, and to members of the Mississippi Department of Transportation Soil Mechanics Laboratory, who assisted in the analysis of soil samples, provided soil and foundation reports, and freely gave advice in the course of bankstability analysis. 


\section{DETERMINATION OF LATERAL BANK MOVEMENT}

Lateral bank movement was determined primarily by the use of historical aerial photography in conjunction with a geographic information system. USGS 7.5-minute topographic quadrangle maps served as base maps for the GIS. Mapping error was measured and documented. Sinuosity [ratio of the length of the channel or thalweg to the down-valley distance (Leopold and Wolman, 1957)] was also monitored at both study sites.

\section{Aerial Photography Mapping}

Historical aerial photography (1942 to 1985) was used in conjunction with USGS 7.5-minute topographic quadrangle maps to determine cartesian coordinates of tops of channel banks, channel-bank widths and lengths, and land use in the stream drainage basins, and to identify channel changes over time for the selected study sites. Scale-stable, acetate-film positives of USGS 7.5-minute quadrangle maps were the base maps on which all channel boundaries identified from aerial photographs were mapped. The USGS quadrangle maps also were used in conjunction with the aerial photographs to help delineate various land-use features.

Aerial photographs were manually referenced to USGS quadrangle maps using houses, roads, powerline right-of-ways, railroads, section lines, and other political boundaries and cultural features that were identifiable both on the aerial photograph and the USGS quadrangle map. Tops of channel banks were transferred from the aerial photographs to scale-stable acetate film which was punch registered to the acetate-film positives of the USGS quadrangle maps using an Aus Jena Sketchmaster ${ }^{1}$. The sketchmaster allowed the photographs to be mechanically registered to the stable base by adjusting scale differences between the photographs and base maps. Tops of banks were delineated on the aerial photographs on the basis of topography and botanical evidence. In study areas that encompass more than one USGS quadrangle map, the edges of these maps were matched during the map compilation phase.

\section{Mapping Error}

Error is inherent in all maps. The national mapping accuracy standards of the USGS for 7.5-minute topographic quadrangle maps allow for a maximum horizontal error of $0.02 \mathrm{in}$. On the map (40-ft of distance) at a map scale of $1: 24,000$ for 90 percent of the points tested. At this sçale, the width of a line $(0.3 \mathrm{~mm})$ drawn on the map with a sharp pencil represents a ground distance of about $25 \mathrm{ft}$. Other errors encountered included those related to the difficulties in defining the tops of banks on the aerial photographs due to riparian vegetation

1 The use of trade or product names in this report is for identification purposes only, and does not constitute endorsement by the U.S. Geological Survey. 
(tree crowns, shrubs, and grasses) indigenous to the channel banks. Shadows cast by riparian vegetation can make defining the true top of bank difficult. Therefore, error is introduced in the photointerpretation of the top of bank. Errors are also introduced by the manual digitization of tops of channel banks into the GIS. Errors introduced by the width of the pencil line, tree crowns defining top of channel-bank conditions, and shadows were presumed random.

Every practical effort was made to eliminate error during map compilation. All mapping was done to a consistent horizontal datum [North American Datum of 1927 (NAD27) or North American Datum of 1983 (NAD83)]. A 0.3-mm line was used to draft features onto base maps. Results of errors in photographic referencing to base maps are called displacement errors. Displacement error was quantitatively evaluated by mapping and digitizing a part of a given study area twice; an example is shown in figure 2. Maximum displacement error was about $60 \mathrm{ft}$. This error was assumed to occur as much on one side of a given top of bank as on the other and was, therefore, nonsystematic.

\section{Sinuosity Computation}

Sinuosity was determined for both sites using data obtained from historical aerial photographs. Down-valley length was obtained at each site from acetatefilm positives of USGS 7.5-minute quadrangle maps. River length was determined for each study reach using drafting dividers and the photointerpreted acetate-film overlay. Valley lengths for the study reaches used in this study to monitor change in sinuosity at the two sites are $8.3 \mathrm{mi}$ for the Chickasawhay River at State Highway 63 at Leakesville and $7.0 \mathrm{mi}$ for the Leaf River at U.S. Highway 98 near McLain. Changes in sinuosity within these reaches are assumed to be representative of the activity of the meandering regime in the vicinity of the two crossings.

\section{Geographic Information System}

One of the tools used to study patterns of channel changes over time was a geographical information system. GIS technology provided a means for storing, displaying, and referencing digital data related to channel location. Some modification of existing GIS software was necessary to facilitate the detection of channel boundary changes with time.

After all photographic data were quantified and entered into the GIS, historical channel meandering was studied to determine patterns of change (for example, movement of channel center lines or top of channel-bank lines with time). Lateral movement of top of channel-bank lines was compared for each year of photographic coverage. Movement and change in eroding channel banks were documented. 


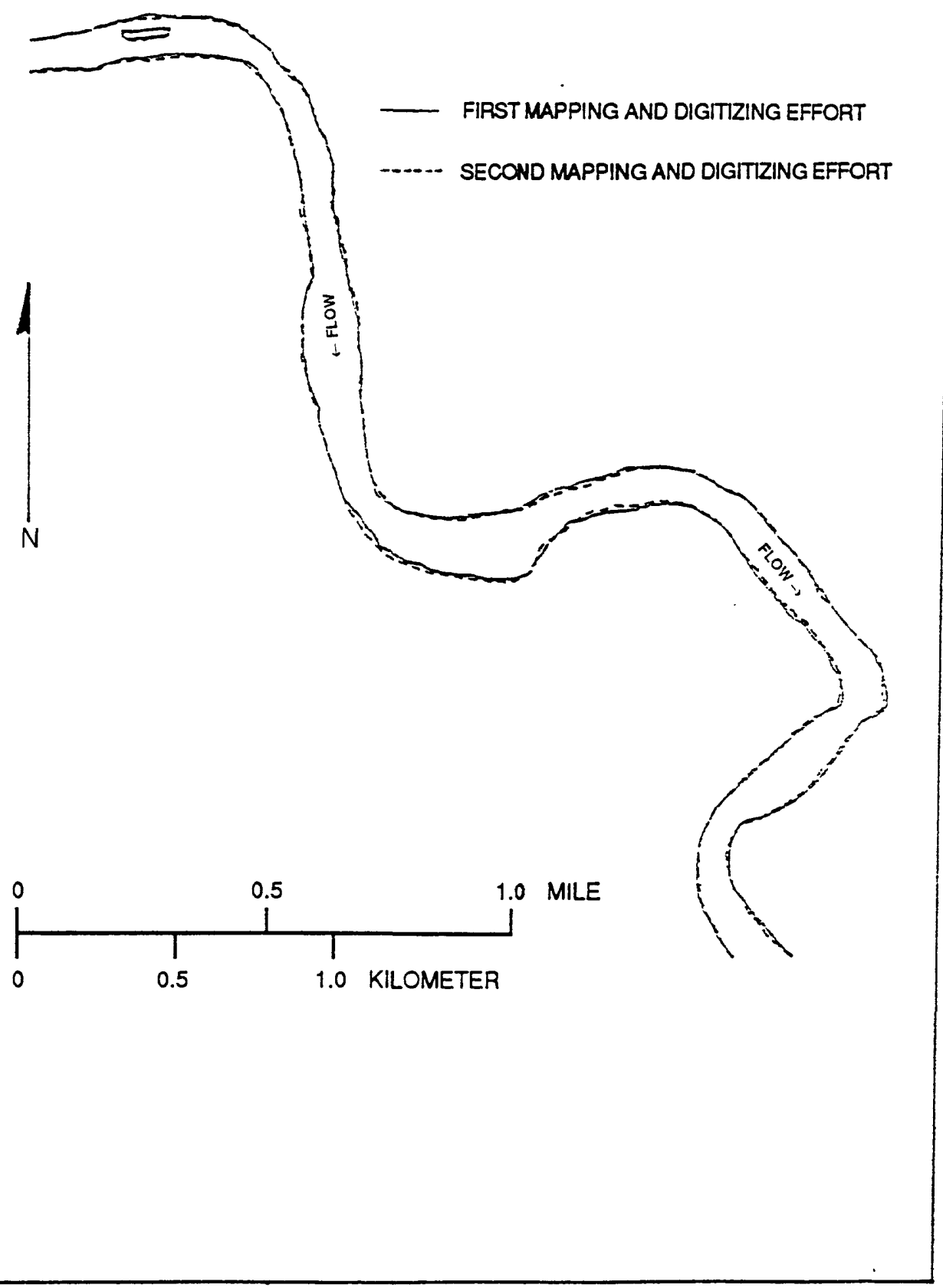

Figure 2.-- Example of channel banks and apparent channel shift caused by errors introduced during mapping and digitizing tops of channel banks for the Pearl River in the vicinity of U.S. Highway 84 near Monticello, Mississippi. 


\section{CHANNEL STABILITY}

Channel-bank stability was monitored by collecting and analyzing existing soil-strength properties of channel banks in the vicinity of both crossings and by analysis of historical and recent channel geometry from discharge measurements by personnel of the USGS at both crossings. Results of slope-stability analyses from existing soil-strength properties and channel geometry were compared to channel-bank movement documented by historical and recent geometry from discharge measurements.

\section{Soil Properties}

General and site-specific soils data were collected at both study sites. MDOT soil and foundation reports were used to obtain soils data along reaches of both study streams. Shear-strength properties (such as cohesion and angles of internal friction) of channel banks on the eroding bends of channel meanders were determined and entered into the GIS.

Cohesion and angle of internal friction values for bank material were measured as needed using the Iowa Borehole Shear Tester (BST). This unit is an in situ soil shear-strength tester (Handy and Fox, 1967). Data obtained using the BST correlate well with standard laboratory unconfined shear-strength tests (Thorne and others, 1981; Wilson and Turnipseed, 1989). Shear-strength properties of bank materials in combination with hydraulic data were used to better correlate existing channel-bank stability data.

\section{Channel-Bank Geometry}

Channel-bank geometry was determined from data obtained during numerous discharge measurements at both study sites. Discharge measurements are made from the bridges at these sites during high flows using a current meter attached to a sounding weight. During discharge measurements, depth soundings are measured across the upstream or downstream side of the bridge(s). These soundings provided channel-bank geometry or cross-sectional data in the vicinity of the bridges at both study sites. Cross sections taken from discharge measurements at the bridges at both study sites indicate changes that have occurred at these bridges during the period since stream gages have been operated at the sites (figs. 3 and 4).

\section{ANALYSIS OF CHANNEL CHARACTERISTICS}

Analysis of channel characteristics at the two sites involved determination of channel-bank movement from channel meander maps; analysis of channelbank stability for existing conditions; and analysis of channel geometry. Results of these analyses provide insight into predicting rates and direction of lateral movement of channels at selected sites in Mississippi. 


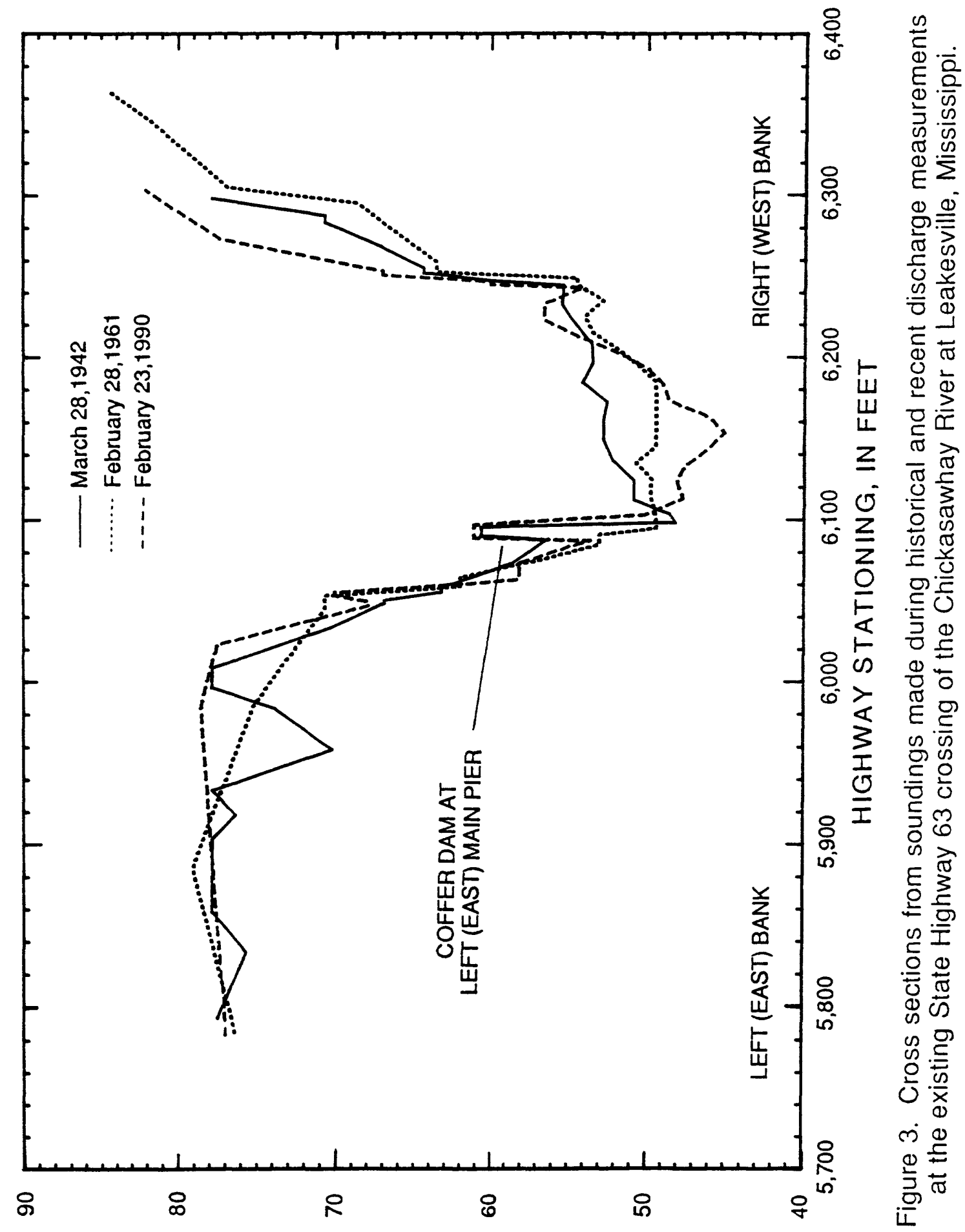

$W \cap \perp \forall O N O I \perp \forall \perp \forall O d S N \forall \forall \perp \pm O \perp N \exists W \perp \forall \forall d \exists O$ IddISSISSIW $\exists \wedge$ O $\forall \perp \exists \exists \exists \mathrm{NI}$ 'NOI $\forall \wedge \exists 7 \exists$ 


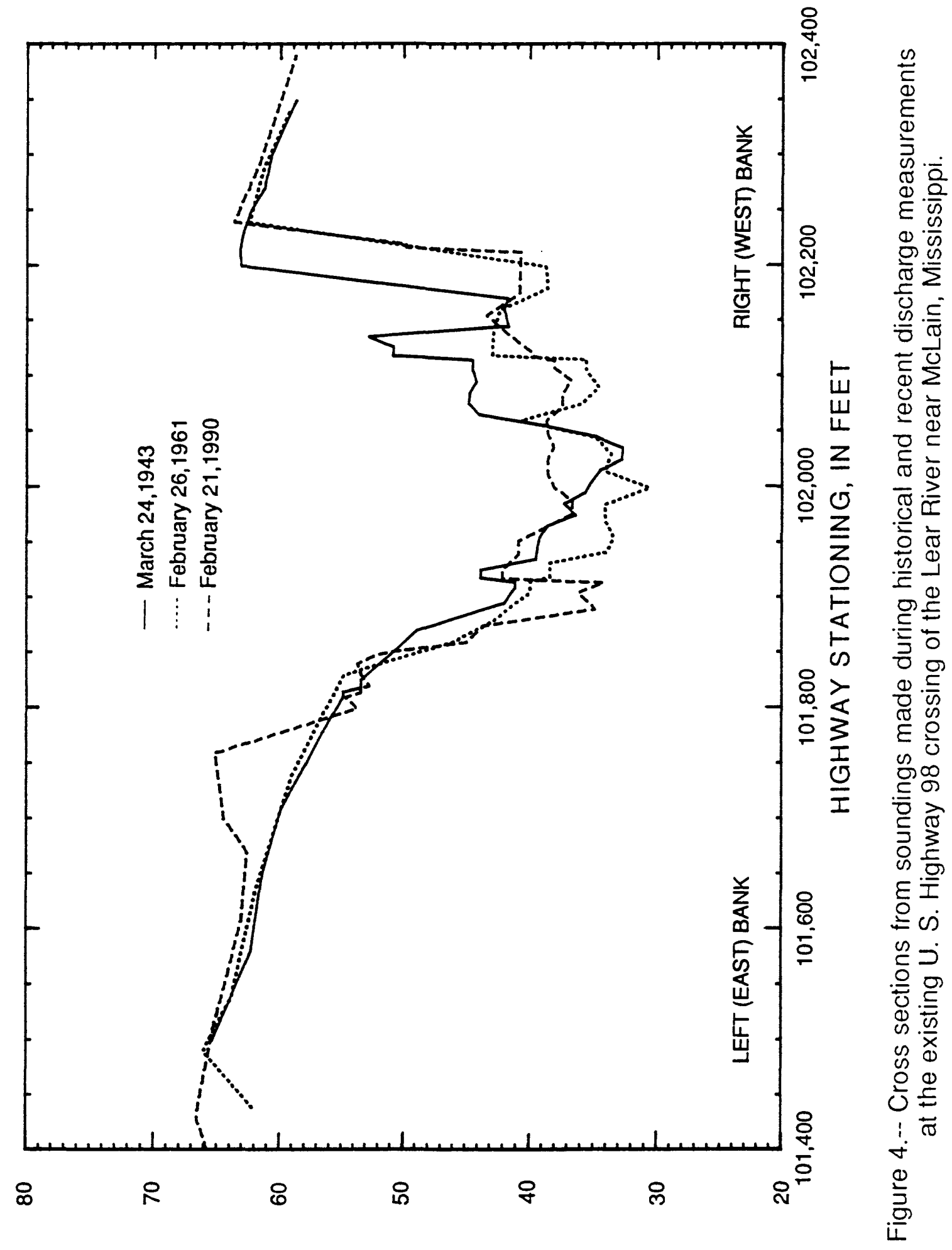

$W \cap \perp \forall O N O I \perp \forall \perp Y O d S N \forall Y \perp \pm O \perp N \exists W \perp \forall \forall d \exists a I d d I S S I S S I W$ $\exists \wedge$ O $\forall \perp \exists \exists \exists N \mathrm{NI}^{\prime} \mathrm{NOI} \perp \forall \wedge \exists 7 \exists$ 


\section{Bank Movement}

Lateral movement of channel banks near the existing and proposed State Highway 63 crossings of the Chickasawhay River and the existing and proposed U.S. Highway 98 crossings of the Leaf River was measured by analysis of historical aerial photography. The aerial photography was then compiled onto acetate film punch registered and overlain on scale-stable positives of USGS topographic quadrangle maps with an Aus Jena Sketchmaster. These data were then digitized and entered into a vector-based GIS data base. Channel geometry (cross sections determined from field surveys and discharge measurements at the study sites) and soil-strength properties of channel banks were used to confirm movement and quantify stability of channel banks within selected studyarea reaches. The results quantify movement of the tops of channel banks at both sites over about a 50 -year period (figs. 5 and 6).

Meander movement near the State Highway 63 crossing of the Chickasawhay River at Leakesville was minimal during the time interval studied. The centerline of the proposed alignment is about $640 \mathrm{ft}$ upstream of the existing alignment. Discussions of movement of meanders are referenced to the existing alignment. About $1.0 \mathrm{mi}$ upstream of the existing bridge, a meander cutoff (meander 1, fig. 5) was formed between 1942 and 1952 creating a oxbow lake on the left (east) bank, apparently due to a series of floods which varied in recurrence interval from less than 2 years to less than 10 years. The vertex (point of maximum change in flow direction) of meander 1 moved from about $5,040 \mathrm{ft}$ upstream of the existing bridge to about $3,900 \mathrm{ft}$ upstream of the bridge from 1942 to 1970, and the vertex moved an additional $300 \mathrm{ft}$ to about $3,600 \mathrm{ft}$ upstream of the existing bridge from 1970 to 1985. The vertex of a right (west) cut bank (meander 2, fig. 5) of the meander cutoff moved downstream about $500 \mathrm{ft}$ from 1942 to 1970 (about 4,100 ft upstream of the existing bridge), and moved about $400 \mathrm{ft}$ farther downstream from 1970 to 1985 (about 3,700 ft upstream of the existing bridge). The western lateral location of the vertex of the right (west) cut bank was about $450 \mathrm{ft}$ from the top of the right (west) bank near the existing and proposed bridges in 1942, about $380 \mathrm{ft}$ in 1970, and about $200 \mathrm{ft}$ in 1985, indicating an eastward movement of meander 2.

The vertex of a left (east) cut bank (meander 3, fig. 5) migrated downstream about $700 \mathrm{ft}$ from 1942 to 1985 . The vertex was about 2,400 ft upstream of the existing bridge in 1942, about 2,100 ft upstream in 1970, and about $1,700 \mathrm{ft}$ upstream and nearing the proposed bridge opening in 1985. Maximum lateral movement to the east of meander 3 was measured to be about $250 \mathrm{ft}$ east of the existing top of bank at the existing State Highway 63 crossing in 1985. 


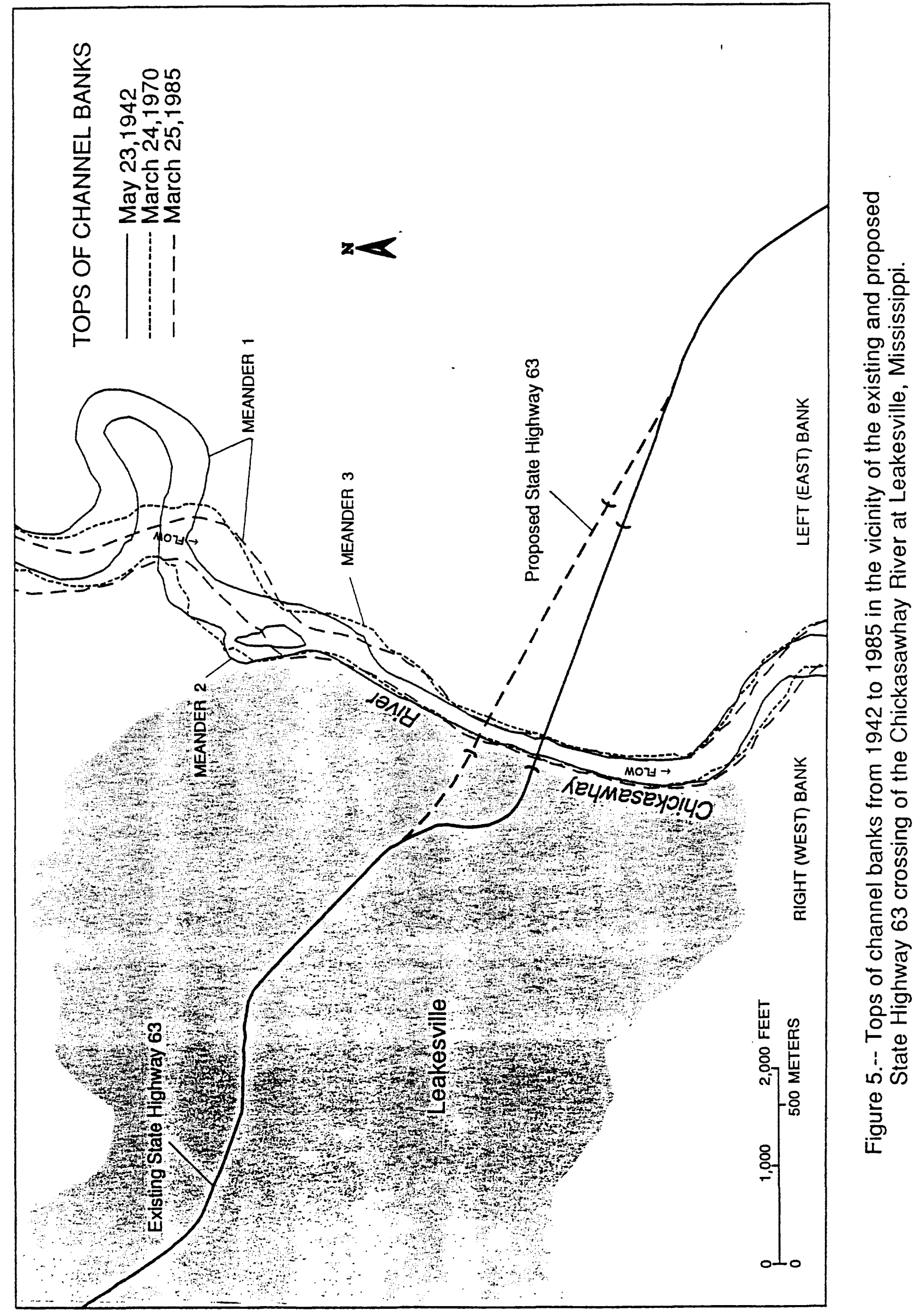




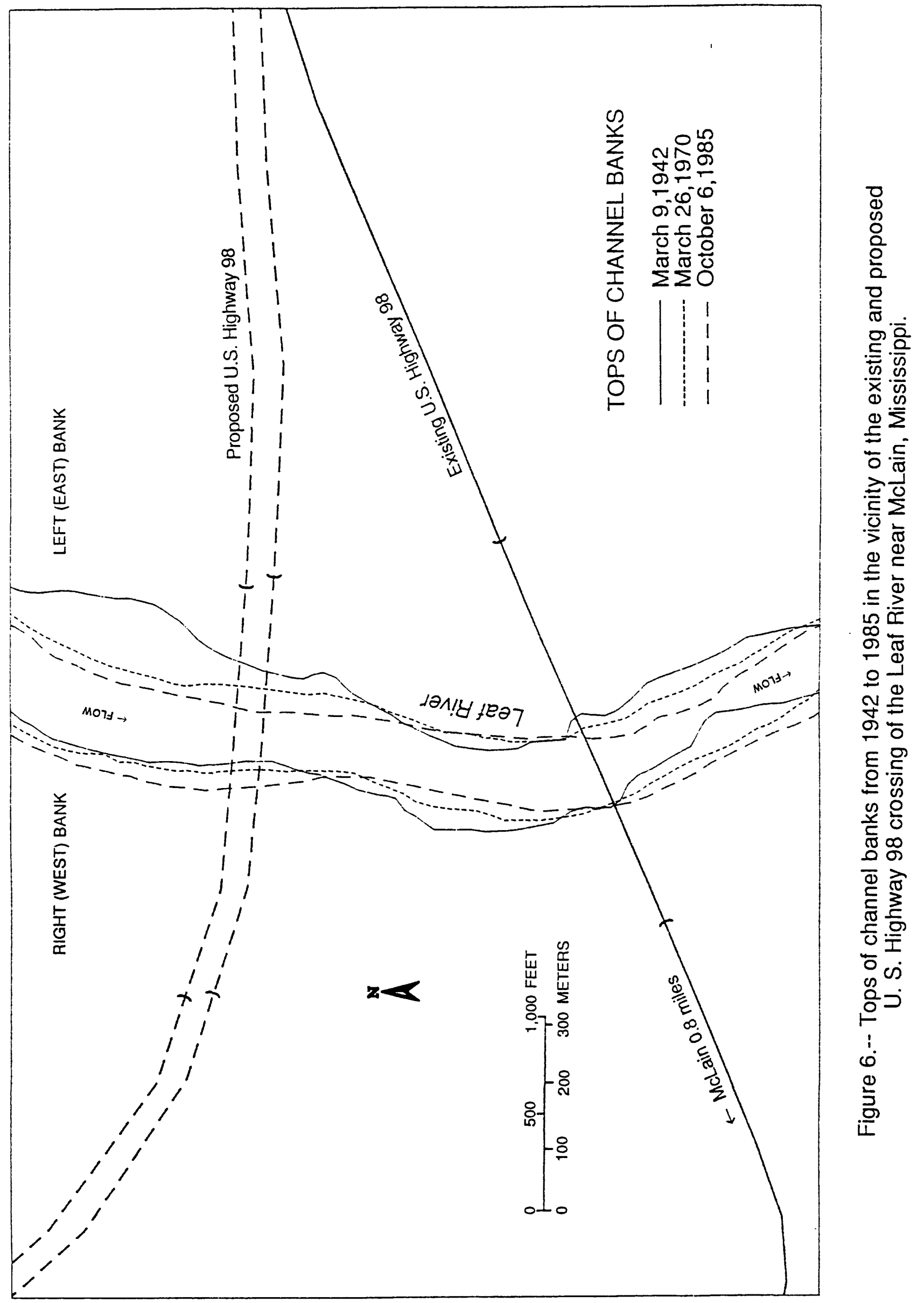


Movement of the channel banks near the existing U.S. Highway 98 crossing of the Leaf River near McLain has been minimal since H-pile spurs were constructed on the upstream right (west) bank in 1952 (fig. 6). The centerline of the proposed alignment is about $1,800 \mathrm{ft}$ upstream of the existing alignment.

Aerial photography of the proposed U.S. Highway 98 crossing of the Leaf River indicate movement of the channel banks was fairly significant in the 44-year span at the site. The longitudinal movement of the vertex of a meander about $1,300 \mathrm{ft}$ upstream of the proposed U.S. Highway 98 crossing has not been significant in the downstream direction, but about $440 \mathrm{ft}$ of westward movement of the left (east) bank and about $120 \mathrm{ft}$ of westward movement of the right (west) bank occurred between 1942 and 1985 (fig. 6). Movement of the left (east) bank resulted in a sand bar formation, whereas movement of the right (west) bank cut into existing channel-bank material. Movement of the channel upstream and downstream of the proposed bridge indicates some instability of the channel banks at this site.

No significant changes in sinuosity occurred in the vicinity of the State Highway 63 crossing of the Chickasawhay River at Leakesville or the U.S. Highway 98 crossing of the Leaf River near McLain during the time period studied (fig. 7). About $0.8 \mathrm{mi}$ upstream of the existing State Highway 63 crossing of the Chickasawhay River a cutoff formed after 1942 which slightly lowered sinuosity at this site from 1.35 to 1.29 between 1942 and 1952. From 1952 to 1985, sinuosity at this site remained constant. No change in sinuosity was detected at the U.S. Highway 98 crossing of the Leaf River near McLain (fig. 7). Average sinuosity was greater at the Leaf River site than at the Chickasawhay River site, probably due to the larger drainage area of the Leaf River, which results in greater discharges. Channel gradient has an inverse relation to stream discharge because as discharge increases, the channel cross section increases, reducing proportionately the frictional losses of the stream and enabling it to carry its bed load on a lesser slope. The development of a meander reduces the gradient of the stream by lengthening its course. Increased sinuosity is a result of the larger radius of curvature of the meanders. It should be noted that changes in sinuosity for the river reaches studied do not represent changes for the entire channel length.

\section{Bank Stability}

Channel-bank stability was analyzed to obtain factors of safety for potential bank failures. The factor of safety is defined here as a ratio of the resisting force (shear strength) of the bank to the driving force (weight) of the bank material as it applies to a critical failure surface. When the resisting force is equal to the driving force (factor of safety = 1.0) bank failure is imminent (Huang, 1983). Generally, a factor of safety of at least 1.5 is used for design. These analyses are computed for banks without the effect of standing water, riprap revetment, tree 


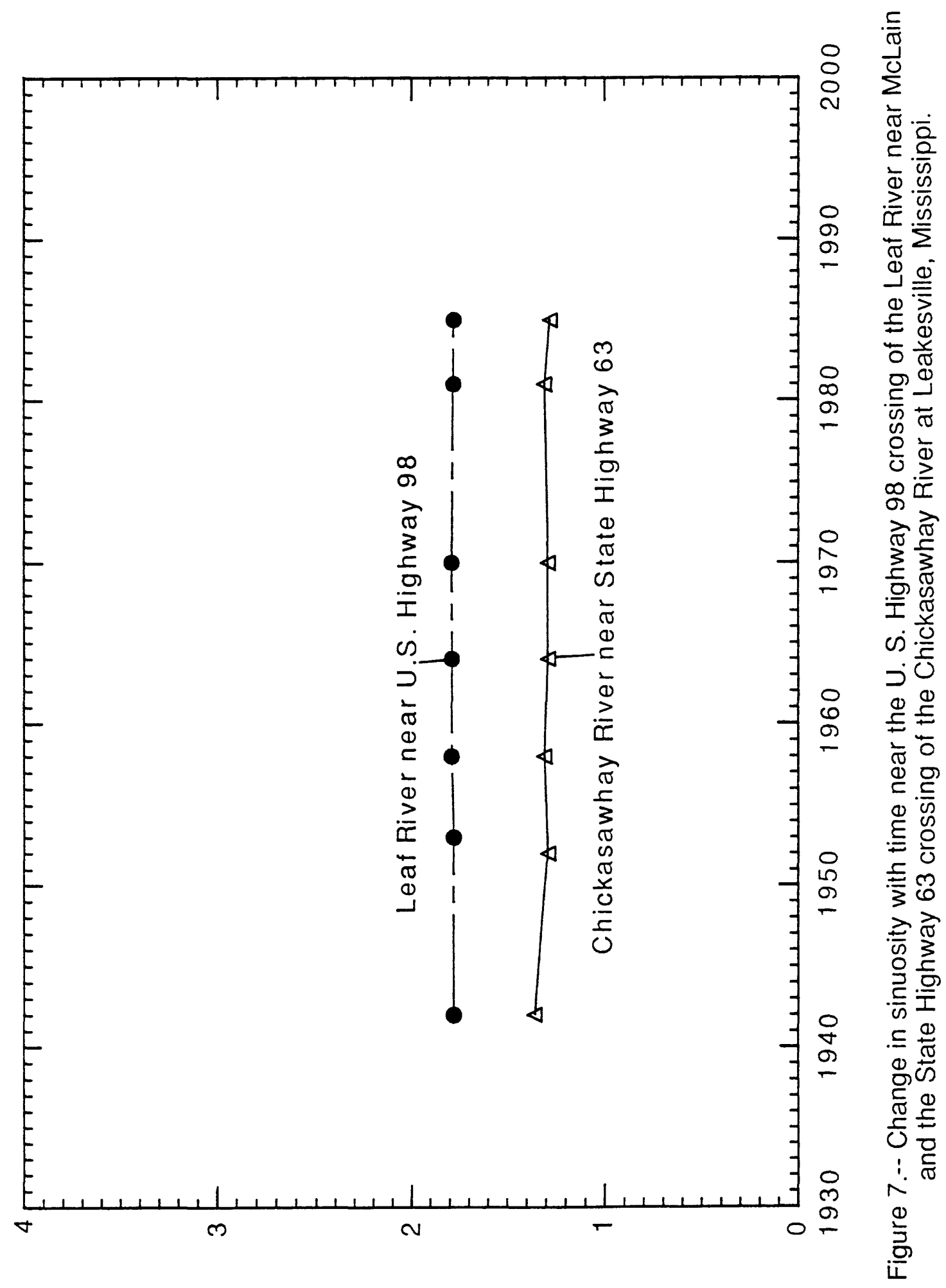

NLISONNIS 
roots or other forces that could strengthen or weaken the bank. No attempt was made to estimate boundary stress resulting from the flow of water.

Values of soil strength properties and channel geometry were entered into software developed by Wright (1986) to obtain probable factors of safety and critical failure surfaces in the vicinity of both sites (figs. 8 and 9). Channel stability analyses were computed at the existing roadway crossings and for cross sections at the proposed crossings, where possible.

MDOT geotechnical investigations were used to obtain soil properties for both sites (Mississippi State Highway Department, 1988 and 1991). Soil properties were also obtained about $300 \mathrm{ft}$ downstream of the State Highway 63 crossing of the Chickasawhay River at Leakesville using the BST. For the purposes of this report, results are presented only for cross sections at the existing bridge crossings of both sites. These results are assumed to be representative of the conditions at the proposed alignments at both sites. Factors of safety computed for the two sites ranged from 0.7 to 1.1.

Channel-bank stability analyses for the existing and proposed State Highway 63 crossings at Leakesville indicate that these sites have factors of safety ranging from 0.7 to 0.9 (fig. 8) which are slightly lower than factors of safety computed for the Leaf River site. MDOT geotechnical reports and soil properties determined by USGS personnel at the site indicate the banks in the vicinity of the existing and proposed State Highway 63 crossings of the Chickasawhay River at Leakesville are composed of mostly medium grained sands and silty sands with little cohesion.

Channel-bank stability analyses for the existing U.S. Highway 98 crossing of the Leaf River near McLain indicate factors of safety of 1.1 for both banks (fig. 9). These relatively low factors of safety are due in part to the large amount of sand contained in the bank material. Soil indices from a MDOT geotechnical report indicate the right (west) bank is composed of loose silts and sands and the left (east) bank is composed of loose silts, loose silty sands, and medium-to-stiff silty clays.

\section{Channel Geometry}

Channel geometry was determined from historical and recent crosssectional data from discharge measurements made at the existing State Highway 63 crossing of the Chickasawhay River at Leakesville and at the existing U.S. Highway 98 crossing of the Leaf River near McLain. Channel geometry or crosssectional data were taken from the downstream sides of the bridges at both study sites (figs. 3 and 4) and served as indicators of channel-bed and channelbank conditions through time. Cross sections at the existing State Highway 63 crossing of the Chickasawhay River at Leakesville indicate that neither bank of the Chickasawhay River crossing migrated significantly from 1942 to 1990 . There is an indication of aggradation of the right (west) bank between 1942 and 1961, 


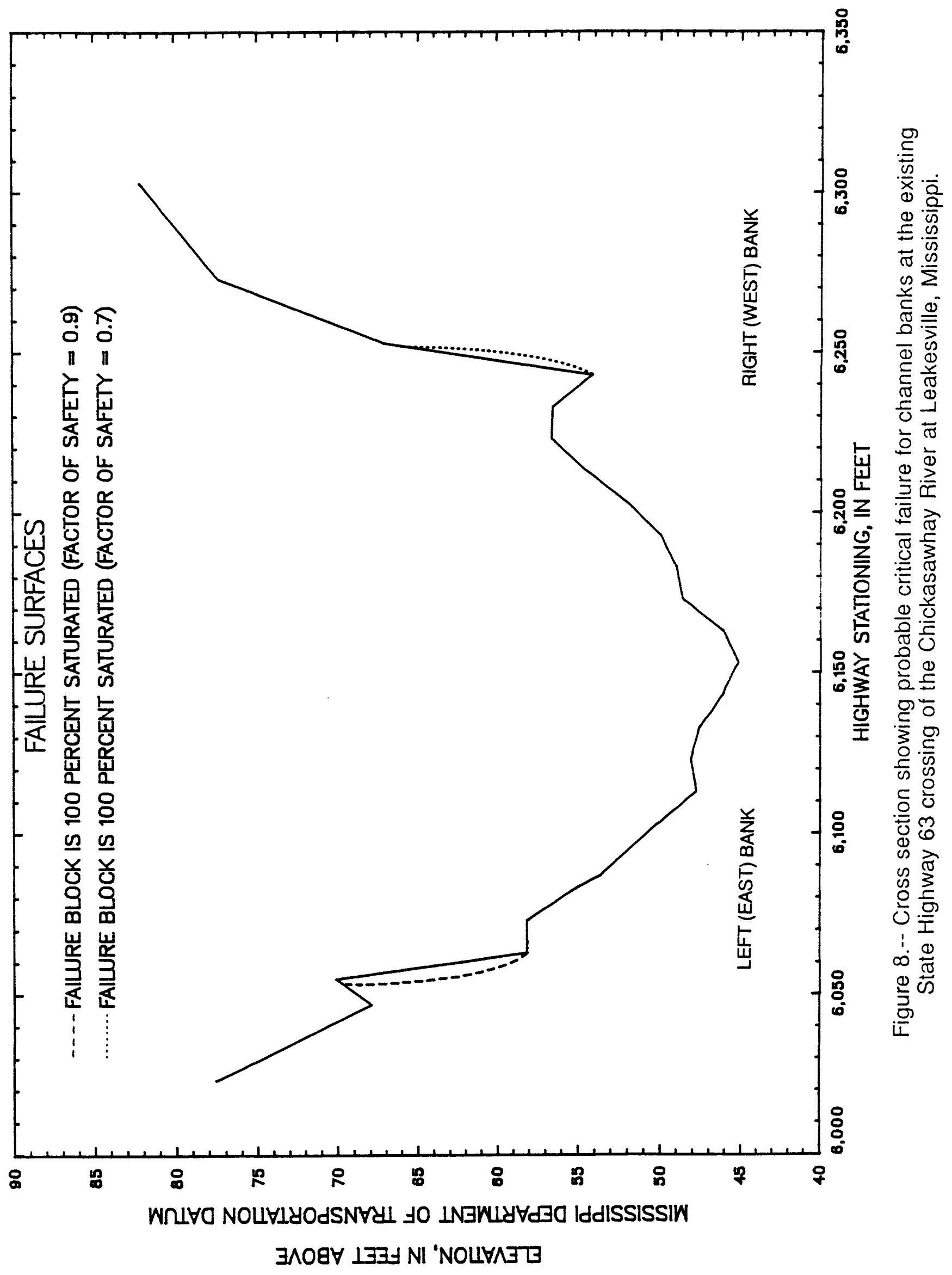




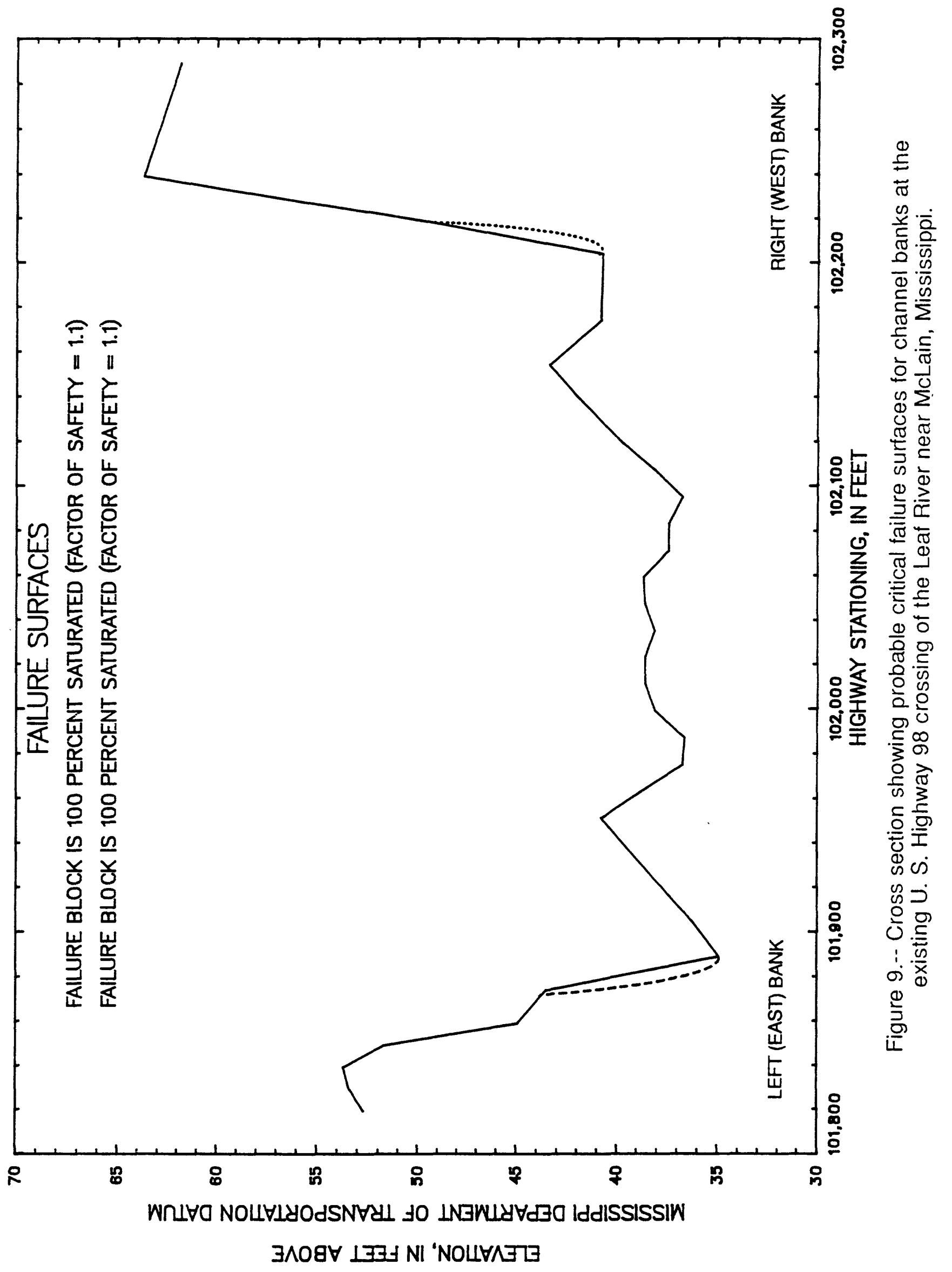


but no measurable change occurred for the top of the right (west) bank from 1942 to 1990 . The thalweg, however, has deepened about $7 \mathrm{ft}$ at the location of the cross section (fig. 3). Streamflow through constricted openings (such as a bridge) can cause local scour and fill of the channel bed in the vicinity of the constriction that may not represent the channel-bed conditions outside the effect of the constriction.

Cross sections from discharge measurements from the downstream side of the bridge indicate the west bank of the existing U.S. Highway 98 crossing of the Leaf River near McLain moved west about $40 \mathrm{ft}$ between 1943 and 1961, but no bank movement occurred between 1961 and 1990 (fig. 4). In 1952, two steel $\mathrm{H}$-pile spurs were constructed upstream of the bridge on the west bank. Horizontal timber sheathing was bolted to the upstream face of the spurs. Rock riprap was placed around pilings under the bridge on the west bank (Brice and others, 1978). In 1992 these spurs were on dry ground during low flow indicating that the low water channel has returned to its original location as indicated by the 1943 cross section. The cross sections (fig. 4) also indicate significant scour and fill (as much as $8 \mathrm{ft}$ ) of the channel bed at the bridge over the 48-year period of study at the Leaf River at the existing U.S. Highway 98 crossing.

\section{SUMMARY}

The meandering of alluvial streams has caused localized channel-bank instability that has endangered bridge structures in Mississippi. The lateral movement of two sites in the Pascagoula River Basin was studied by mapping meanders at various times and measuring channel geometry and soil strength properties at these sites. This study has provided information useful in determining past channel conditions at both sites.

Although severely cutting meanders are characteristic of both rivers studied, none were located near either the existing or proposed bridges. The development of cutbanks upstream of both proposed crossings could cause unstable banks at both sites.

Cartesian coordinates representing tops of channel banks were determined from historical aerial photographs. Channel-bank tops were delineated on the aerial photographs and transferred to scale-stable material overlain on acetatefilm positives of USGS 7.5-minute quadrangle maps. Although some error was introduced in delineating and transferring bank lines in this manner, most errors introduced in this process were small and were assumed to be non-systematic. A geographic information system provided a means of storing, displaying, and referencing the tops of channel banks through time at both sites.

No recent significant lateral movement of channel banks was detected at the existing State Highway 63 crossing of the Chickasawhay River or at the 
existing U.S. Highway 98 crossing of the Leaf River based on mapped tops of channel banks and historical and recent channel geometry. Maps of tops of channel banks at the proposed alignments of both crossings, however, indicated lateral movement with time. A maximum of about $250 \mathrm{ft}$ of eastward movement of the left (east) bank occurred in a reach upstream of the existing State Highway 63 crossing of the Chickasawhay River. A maximum of about $440 \mathrm{ft}$ of westward movement of the left (east) bank and about $120 \mathrm{ft}$ of westward movement of the right (west) bank occurred in a reach upstream of the proposed U.S. Highway 98 crossing of the Leaf River.

Mapped tops of channel banks generally correlated well with channel geometry determined from discharge measurements made at the bridges. Bankstability analyses at and near the U.S. Highway 98 and State Highway 63 crossings of the Leaf and Chickasawhay Rivers indicated factors of safety less than 1.5 (the design factor of safety). Relatively low factors of safety near both sites are probably due to the large amount of sand composing the channel banks at these sites. No attempt was made in this study to consider the effect of boundary stress from stream power on lateral bank movement. Stability analyses were also computed for banks without the effect of standing water, riprap revetment, tree roots and (or) other forces that could strengthen or weaken the bank.

Channel cross sections obtained at the existing State Highway 63 crossing of the Chickasawhay River between 1942 and 1990 indicated significant scouring of the thalweg (about $7 \mathrm{ft}$ ). Channel cross sections at the U.S. Highway 98 crossing of the Leaf River indicated significant local scour (as much as $8 \mathrm{ft}$ ) of the channel bed during floods. Channel-bed scour at this crossing probably is spatially and temporally limited. Also, some movement of the west bank at the U.S. Highway 98 crossing of the Leaf River was indicated between 1942 and 1952, but this bank seems to have stabilized after installation of H-pile spurs in the 1950's at the upstream side of the right (west) bank at the existing bridge. Change in sinuosity was not significant at the two sites. Sinuosity was lower on the Leaf River, probably due to its larger drainage area. 


\section{REFERENCES}

Brice, J.C., Blodgett, J.C., and others, 1978, Countermeasures for hydraulic problems at bridges; Volume 2, Case Histories for Sites 1-283: Federal Highway Administration, Offices of Research and Development Report No. FHWA-RD-78-163, $542 \mathrm{p}$.

Handy, R.L., and Fox, N.W., 1967, A soil bore-hole direct-shear device: Highway Research News No. 27, p. 42-51.

Huang, Y.H., 1983, Stability analysis of earth slopes: Van Nostrand Reinhold Company, Inc., 305 p.

Landers, M.L., and Wilson, K.V., Jr., 1991, Flood characteristics of Mississippi streams: U.S. Geological Survey Water-Resources Investigations Report 91-4037, $82 \mathrm{p}$.

Leopold, L.B.,and Wolman, M.G., 1957, River channel patterns--braided, meandering, and straight: U.S. Geological Survey Professional Paper 282-B, p. 39-85.

Linsley, R.K., Jr., Kohler, M.A., and Paulhus, J.L.H., 1982, Hydrology for engineers ( $3 d$ ed.): McGraw-Hill, 508 p.

Mississippi State Highway Department, 1988, Geotechnical investigation of U.S. Highway 98 across Leaf River, U.S. Highway 98 across Big Oktibee Creek, Green County, Mississippi: Report to Garver and Garver, P.A., Little Rock, Arkansas: Burns Engineering, Inc., Jackson, Miss., 18 p., 97 pl.

Mississippi State Highway Department, 1991, Geotechnical investigation of Mississippi 63 over Chickasawhay River, Greene County, Mississippi: Report to Neel-Schaffer, Inc. Jackson, Miss.: Ware, Lind, Furlow Engineers, Inc., Jackson, Miss., 21 p., 170 pl.

Nanson, G.C. and Hickin, E.J., 1986, A statistical analysis of bank erosion and channel migration in western Canada: Geological Society of America Bulletin, v. 97, p. 497-504.

Osman, A.M. and Thorne, C.R., 1988, River stability analysis I: Theory, in Journal of Hydraulic Engineering: American Society of Civil Engineers, v. 114, no. 2, p. 134-150.

Shen, H.W. (ed.), 1971, River mechanics: Volume I: Colorado State University Department of Civil Engineering, p. 1-1 to 19-79. 
Thorne, C.R., Murphey, J.B., and Little, W.C., 1981, Stream channel stability, Appendix D, Bank stability and bank material properties in the bluffline streams of northwest Mississippi: U.S. Department of Agriculture Sedimentation Laboratory, Oxford, Miss., 257 p.

U.S. Department of Transportation, Federal Highway Administration, 1975, Highways in the river environment--Hydraulic and environmental design considerations: Civil Engineering Department Engineering Research Center, Colorado State University, Fort Collins.

Wilson, K.V., Sr., 1979, Changes in channel characteristics, 1938-74, of the Homochitto River and tributaries, Mississippi: U.S. Geological Survey Open-File Report 79-554, 18 p.

Wilson, K.V., Jr., and Landers, M.N., 1991, Annual peak stages and discharges for streamflow-gaging stations in Mississippi: U.S. Geological Survey Water-Resources Investigations Report 91-4098, 705 p.

Wilson, K.V., Jr., and Turnipseed, D.P., 1989, Channel and bank stability of Big Black River Canal tributary at U.S. Highway 82 at Stewart, Montgomery County, Mississippi: U.S. Geological Survey Open-File Report 89-35, 16 p.

Wright, S.G., 1986, UTEXAS2 (University of Texas Analysis of Slopes - Version 2): A computer program for slope stability calculations: Geotechnical Engineering Software GS86-1, Geotechnical Engineering Center, Civil Engineering Department, University of Texas at Austin. 